\author{
І.Л. Костенко ${ }^{1}$, В.П. Поздняк ${ }^{1}$, С.М. Блащук ${ }^{1}$, О.О. Казіміров ${ }^{2}$, В.В. Поляцко ${ }^{3}$ \\ ${ }^{1}$ Харківський національний університет Повітряних Сил ім. І. Кожедуба, Харків \\ ${ }^{2}$ Начіональна академія Наџіональної гвардії Украӥни, Харків \\ ${ }^{3}$ Штаб Командування Об’єднаних сил Збройних Сил України, Київ
}

\title{
МЕТОДИКА АВТОМАТИЗОВАНОГО РОЗРАХУНКУ РАДІОЛІНІЙ ПРИ ЗВ'ЯЗКУ ЗЕМНОЮ ХВИЛЕЮ
}

\begin{abstract}
В статті наведена методика автоматизованого розрахунку радіолінї̈ при зв'язку земною хвилею у діапазонах кілометрових, гектометрових та декаметрових хвиль з метою визначення граничної дальності забезпечення радіозв'язку (радіонавігаџіï) з заданою якістю за допомогою прикладного математичного пакету Mathcad. Відомо, щуо гранична дальність радіозв'язку (радіонавігачї) досягається тоді, коли реальне послаблення, яке визначається поглинанням на трасі поширення, дорівнює гранично допустимому послабленню, яке залежить від завадової обстановки в точиі прийому, необхідної якості прийому і технічних характеристиках передавального і приймального пристроїв. Гранично допустиме послаблення на трасі визначаються, виходячи з основного рівняння радіозв'язку та умови здійснення радіозв'язку. Реальне (фактичне) послаблення сигналу на трасі поширення розраховується з урахуванням множника послаблення на будьякій трасі. Рішення дифракиійної задачі полягає в розв'язанні хвильового рівняння в сферичній системі координат при встановлені граничних умов на поверхні гладкої землі і врахуванні особливостей характеристик поля поблизу випромінювача.
\end{abstract}

Ключові слова: дальність радіозв'язку, допустиме послаблення, дифракція, земна хвиля, електричні параметри трунту, Mathcad, поширення радіохвиль.

\section{Вступ}

Постановка проблеми. На практиці часто потрібно оцінити граничну дальність забезпечення радіозв'язку (радіонавігації) земною хвилею з заданою якістю. Методика вирішення даного завдання графо-аналітичним способом у діапазонах кілометрових, гектометрових та декаметрових хвиль відома i доведена до інженерного рівня. Але вона може бути застосована на практиці лише фахівцем, що має відповідну кваліфікацію.

Крім того, використання даної методики пов'язано з досить трудомісткими в освоєнні та тривалими за часом рутинними розрахунками, а графіки, що запропоновані в “Рекомендаціях MCE-R P.368-9", наведені лише для деяких фіксованих значень частоти, електричних параметрів підстилаючої поверхні і одного значення потужності передавача 1 кВт. 3 цих причин з'являється інтерес в розробці методики чисто аналітичного розрахунку граничної дальності зв'язку земної хвилею і їі “автоматизації”.

Аналіз останніх досліджень і публікацій. Роботи [1-3; 7; 14-15] є важливим внеском у вивченні особливостей розповсюдження радіохвиль земною хвилею. Відомо, що гранична дальність радіозв'язку залежить від завадової обстановки в точці прийому. Дані про рівень індустріальних, атмосферних та станційних завад, необхідні для розрахунку радіолінії, наводяться в [9-11].

Гранична дальність забезпечення радіозв'язку також сильно різниться у залежності від електрич- них параметрів поверхні землі. Мінімальний набір орієнтовних узагальнених значень електричних параметрів та методика їх розрахунку за емпіричними формулами наведені в [8].

У роботах [4-6; 12] пропонуються основи енергетичного розрахунку радіоканалів земною хвилею та чисельні результати теорії дифракції радіохвиль вздовж земної поверхні.

Для автоматизації даних розрахунків з метою оцінки граничної дальності забезпечення радіозв'язку скористаємося прикладним математичним пакетом Mathcad, який наглядно представлено в [13].

Отже, незважаючи на наявність значної кількості наукових досліджень у галузі розповсюдження радіохвиль та розрахунку радіоліній при зв'язку земною хвилею можна зробити висновок про недостатню автоматизацію даних розрахунків для оцінки граничної дальності забезпечення радіозв'язку.

Метою статті $\epsilon$ розробка методики автоматизованого розрахунку радіолінії при зв'язку земною хвилею у діапазонах кілометрових, гектометрових та декаметрових хвиль 3 метою визначення граничної дальності забезпечення радіозв'язку (радіонавігації) з заданою якістю за допомогою прикладного математичного пакету Mathcad.

\section{Виклад основного матеріалу}

Відомо, що гранична дальність радіозв'язку (радіонавігації) досягається тоді, коли реальне послаблення, яке визначається поглинанням на трасі 
поширення, дорівнює гранично допустимому послабленню, яке залежить від завадової обстановки в точці прийому, необхідної якості прийому і технічних характеристик передавального і приймального пристрою.

Гранично допустиме послаблення на трасі $W_{\text {доn }}$ можна знайти виходячи з основного рівняння радіозв'язку та умови здійснення радіозв'язку [2]:

$$
W_{\partial o n}=\sqrt{\frac{h_{0} \cdot k_{L} \cdot B \cdot \eta_{A 2} \cdot\left(T_{a m}+T_{i}+T_{c}\right)}{P_{1} \cdot \eta_{\phi 1} G_{1} \cdot G_{2}}},
$$

де $k_{5}=1,38 \cdot 10^{-23} \mathrm{~B} \mathrm{~T} / Г ц \cdot К-$ постійна Больцмана;

$B$ - смуга пропускання приймача, що визначається видом роботи і максимальною частотою модуляції (наприклад, телефонія двосмугова: $B=6,8 \kappa \Gamma u$, телефонія односмугова: $B=3,4 \kappa \Gamma u$ );

$P_{1}$ - потужність передавача;

$G_{1}$ - коефіцієнт підсилення передавальної антени;

$G_{2}$ - коефіцієнт підсилення приймальної антени;

$\eta_{\phi 1}$ - коефіцієнт корисної дії (ККД) фідера передавальної антени;

$\eta_{A 2}$ - ККД антенно-фідерного тракту приймального пристрою;

$h_{0}=\frac{P_{c}}{\left(P_{n}+P_{u}\right)}-$ коефіцієнт захисту, що характеризує якість зв'язку, та є відношенням потужності нефлюктуюючого сигналу на вході приймача до медіанного значення суми потужностей зовнішніх перешкод і внутрішніх шумів приймача, приведених до його входу, за короткі (близько хвилини) інтервали часу;

$T_{a m}, T_{i}, T_{c}$ - ефективна шумова температура відповідно атмосферних, індустріальних та станційних завад.

Реальне (фактичне) послаблення сигналу на трасі поширення розрахуємо наступним чином.

Множник послаблення на будь-якій трасі доріВнює

$$
W=W_{0} \times W_{T}
$$

де $W_{0}=\frac{\lambda}{4 \pi r}-$ множник послаблення сигналу у вільному просторі;

$\lambda$ - довжина хвилі у вільному просторі;

$r$ - відстань від передавальної до приймальної антени;

$$
W_{T}=\left.\frac{E}{E_{0}}\right|_{r=\text { const }}-\text { множник послаблення, що }
$$

враховує вплив поверхні Землі з іiі електричними параметрами при поширенні радіохвиль на реальній трасі;

$E$ - напруженість поля з урахуванням послаблення на трасі в точці прийому;

$E_{0}$ - напруженість поля без урахування послаблення на трасі в точці прийому.

При виконанні умови $r<20 \cdot \sqrt[3]{\lambda_{M}}$ км однорідну поверхню Землі можна вважати плоскою. При цьому множник ослаблення $W_{T}$ розраховується за методом Шулейкіна - Ван-дер-Поля [2]:

$$
\begin{aligned}
W_{T}(r)= & \frac{2+0,3 \cdot x}{2+x+0,6 \cdot x^{2}}-\sqrt{\frac{x}{2}} \cdot e^{\frac{-5 \cdot x}{8}} \times \\
& \times \frac{\varepsilon}{\sqrt{\varepsilon^{2}+(60 \cdot \lambda \cdot \sigma)^{2}}},
\end{aligned}
$$

де $x=\frac{\pi \cdot r}{\lambda} \cdot \frac{1}{\sqrt{\varepsilon^{2}+(60 \cdot \lambda \cdot \sigma)^{2}}}-$ чисельна відстань для вертикально поляризованої хвилі;

$\varepsilon$ - відносна діелектрична проникність;

$\sigma-$ питома провідність, См/м.

На трасах протяжністю $r \geq 20 \cdot \sqrt[3]{\lambda_{M}}$ км поверхню землі не можна вважати плоскою. Опуклість сферичної землі $є$ перешкодою, і процес поширення радіохвиль визначається їх дифракцією на опуклості землі при відсутності впливу іоносфери, що має місце на відстанях, забагато менших їі радіусу.

Рішення дифракційної задачі полягає в розв'язуванні хвильового рівняння в сферичній системі координат при врахуванні граничних умов на поверхні гладкої землі і особливості поля поблизу випромінювача. Атмосфера вважається однорідною. Поле визначається в точці, розташованій на відстані $r=\alpha \phi$ по дузі великого кола від антени ( $\alpha-$ радіус Землі, $\phi$ - центральний кут).

Рішення задачі дифракції на сфері великого радіусу $(\lambda<<r)$ для множника послаблення має вигляд нескінченного ряду. Для земної хвилі, коли обидві антени знаходяться на поверхні землі, дифракційна формула набуває вигляду [2]:

$$
W_{T}(y, q)=e^{i \cdot \frac{\pi}{4}} \cdot 2 \cdot \sqrt{\pi \cdot y} \cdot \sum_{s=1}^{\infty} \frac{e^{i \cdot t_{s} \cdot y}}{t_{S}+q^{2}},
$$

де $y$ - відносна відстань;

$q$ - параметр для вертикальної поляризації хвилі;

$t_{s}-$ коріння рівняння.

За методом В.А. Фока [7] вводять відносну відстань $x$ розташування антен $x=\frac{r}{L}$, де $L-$ масштаб відстані, що визначається співвідношенням: 


$$
L=\left(\frac{\lambda \alpha^{2}}{\pi}\right)^{\frac{1}{3}}
$$

Параметр $q$ визначається для вертикальної поляризації хвилі формулою:

$$
q=i \cdot \sqrt[3]{\pi \cdot \alpha / \lambda} \cdot \frac{1}{\sqrt{\varepsilon-i \cdot 60 \cdot \lambda \cdot \sigma}},
$$

а через $t_{s}$ позначені коріння рівняння

$$
\omega^{\prime}(t)-q \cdot \omega(t)=0
$$

де $\omega(t)=\sqrt{\pi / 3} \cdot e^{-i \cdot 2 \cdot \pi / 3} \cdot \sqrt{t} \cdot H_{1 / 3}^{(2)} \cdot\left(2 / 3 \cdot \sqrt[3]{t^{2}}\right)-$ фун-

кція Ейрі, що виражається через функцію Ханкеля другого роду порядку $1 / 3$.

Коріння рівняння (7) $t_{s}$ обчислюються за формулами [2]:

$$
\begin{array}{ll}
t_{s} \cong t_{s}^{0}+\frac{q}{t_{s}^{0}} \quad \text { при } \quad\left|q \cdot \sqrt{t_{s}}\right|<1 ; \\
t_{s} \cong t_{s}^{\infty}+\frac{1}{q} \quad \text { при } \quad\left|q \cdot \sqrt{t_{s}}\right|>1,
\end{array}
$$

де $t_{s}^{o}, t_{s}^{\infty}-$ коріння рівняння (7) при $q=0$ та $q=\infty$ відповідно. Перші коріння дорівнюють[1]:

$$
t_{1}^{o}=-0,51+i 0,88, \quad t_{1}^{\infty}=-1,17+i 2,03 .
$$

У міру поглиблення в область геометричної тіні ряд (4) досить швидко сходиться, тому для практичних розрахунків можна обмежитися першим членом ряду. Така “одночленна” формула, що придатна для інженерних розрахунків, має вигляд [1]:

$$
\left|W_{T}(r)\right|=2 \cdot \sqrt{\pi \cdot y(r)} \cdot\left|\frac{e^{i \cdot t_{1} \cdot y(r)}}{t_{1}+q^{2}}\right| .
$$

Розрахунок проведемо за допомогою прикладного математичного пакету Mathcad [13].

Як приклад, при довжині хвилі $\lambda=60 \mu$ визначимося $з$ вихідними даними:

$$
\begin{aligned}
& h_{0 д Б}:=15 \partial Б, k_{Б}:=1.38 \cdot 10^{-23} \mathrm{Bm} / \Gamma u \cdot K, \\
& B:=3400 \Gamma u, \eta_{A 2}:=0.6, \eta_{\phi 1}:=0.5, G_{1}:=2.2, \\
& P_{1}:=1000 B m, G_{2}:=0.6, T_{a m}:=0.8 \cdot 10^{6} \mathrm{~K}, \\
& T_{i}:=0.4 \cdot 10^{8} \mathrm{~K}, T_{c}:=3 \cdot 10^{7} \mathrm{~K} .
\end{aligned}
$$

Підставимо вихідні дані в (1) та знайдемо $W_{\text {доn }}$ :

$$
W_{\partial о n d B}=-130.2 \partial Б .
$$

Проведемо розрахунок граничної дальності забезпечення радіозв'язку при вологому грунті з електричними параметрами: $\varepsilon=10, \sigma=10^{-2}$ См/м. Прирівнявши допустиме ослаблення фактичному, отримаємо $W_{\text {доn }}$, представлений фрагментом Mathcad документа (рис. 1):

$$
\begin{aligned}
& \text { Given } \\
& \begin{array}{l}
\mathrm{W}_{\text {доп }}=\left\lfloor\left[\frac{\lambda}{4 \cdot \pi \cdot \mathrm{r}} \cdot\left[\frac{(2+0.3 \cdot \mathrm{x}(\mathrm{r}))}{\left(2+\mathrm{x}(\mathrm{r})+0.6 \cdot \mathrm{x}(\mathrm{r})^{2}\right)}-\sqrt{\frac{\mathrm{x}(\mathrm{r})}{2}} \cdot \mathrm{e}^{\frac{-5 \cdot \mathrm{x}(\mathrm{r})}{8}} \cdot \frac{\varepsilon}{\sqrt{\varepsilon^{2}+(60 \cdot \lambda \cdot \sigma)^{2}}}\right]\right] \text { if } \mathrm{r}<20 \cdot \sqrt[3]{\lambda} \cdot 10^{3}\right. \\
{\left[\frac{\lambda}{4 \cdot \pi \cdot \mathrm{r}} \cdot\left(2 \cdot \sqrt{\pi \cdot \mathrm{y}(\mathrm{r})} \cdot\left|\frac{\mathrm{e}^{\mathrm{i} \cdot \mathrm{y}(\mathrm{r}) \cdot \mathrm{t}_{1}}}{\mathrm{t}_{1}+\mathrm{q}^{2}}\right|\right)\right] \text { if } \mathrm{r} \geq 20 \cdot \sqrt[3]{\lambda} \cdot 10^{3}}
\end{array} \\
& \text { Find ( } \mathrm{r})=7.593 \times 10^{4} \mathrm{M}
\end{aligned}
$$

Рис. 1. Фрагмент Mathcad документа по обчисленню граничної дальності зв'язку Джерело: розроблено авторами.

Тобто гранична дальність забезпечення радіозв'язку з заданою якістю при вологому грунті дорівнює приблизно 76 км.

При інших електричних параметрах грунту отримаємо таки результати:

- при розповсюдженні радіохвиль над морською поверхнею 3 електричними параметрами: $\varepsilon=80, \sigma=4$ См/м гранична дальність зв'язку дорівнює приблизно 422 км;

- при дуже вологому грунті (заболочена земля влітку, солончаки, вологі торфовища) з електричними параметрами: $\varepsilon=20, \sigma=10^{-1} \mathrm{CM} /$ м гранична дальність зв'язку дорівнює приблизно 175 км;
- при сухому грунті (піщаний і суглинний, скелі, ліс) 3 електричними параметрами: $\varepsilon=5$, $\sigma=10^{-3} \mathrm{CM} /$ м гранична дальність зв'язку дорівнює приблизно 30 км;

- при дуже сухому грунті (пустелі, промерзлий грунт, великі міста та сильно забудована місцевість, гориста місцевість) з електричними параметрами: $\varepsilon=4, \sigma=10^{-4} \mathrm{CM} / \mathrm{M}$ гранична дальність зв'язку дорівнює приблизно 25 км.

Мінімальний набір орієнтовних узагальнених значень вказаних параметрів наведено в табл. 1. 
Таблиця 1

Мінімальний набір орієнтовних узагальнених значень вказаних параметрів

\begin{tabular}{|l|c|c|}
\hline \multicolumn{1}{|c|}{ Вид і стан поверхні } & $\varepsilon$ & $\sigma$, См/м \\
\hline \multicolumn{1}{|c|}{1} & 2 & 3 \\
\hline Море у спокійному стані & 80 & 4 \\
\hline Прісна вода озер і річок & 80 & $10^{-3}$ \\
\hline $\begin{array}{l}\text { Дуже вологий грунт (заболочена } \\
\text { земля влітку, солончаки, вологі } \\
\text { торфовища) }\end{array}$ & 20 & $10^{-1}$ \\
\hline $\begin{array}{l}\text { Вологий грунт (глинистий, чорно- } \\
\text { земний, каштановий при рівнинній } \\
\text { і слабкопересіченій місцевості, що } \\
\text { чергується місцями лісом, який } \\
\text { заповнює до 1/3 траси) }\end{array}$ & 10 & $10^{-2}$ \\
\hline $\begin{array}{l}\text { Сухий грунт (піщаний і суглинний, } \\
\text { скелі, ліс) }\end{array}$ & 5 & $10^{-3}$ \\
\hline $\begin{array}{l}\text { Дуже сухий грунт (пустелі, промер- } \\
\text { злий грунт, великі міста та сильно } \\
\text { забудована місцевість, гориста } \\
\text { місцевість) }\end{array}$ & 4 & $10^{-4}$ \\
\hline
\end{tabular}

Джерело: [8, С. 26].

Розрахунок електричних параметрів підстильної поверхні можна провести за емпіричними формулами

$$
\begin{gathered}
\varepsilon=c w+2 \\
\sigma=7,7 \cdot 10^{-5} \cdot\left(0,73 w^{2}+1\right) \cdot\left(1+0,03 t^{o}\right), \mathrm{CM} / \mathrm{M}
\end{gathered}
$$

де $c$ - константа, що приймає значення:

$0,3 \ldots 0,5$ - для піщаного грунту;

0,5 - для чорнозему (червонозему);

$0,5 \ldots 0,7$ - для глинистого грунту;

$w$ - вологість грунту у відсотках:

$4 \ldots 9 \%$ - піщаний грунт;

$10 \ldots 15 \%$ - вологий пісок;

$18 \ldots 20 \%$ - чорнозем, червонозем;

$20 \ldots 25 \%$ - глинистий грунт;

$t^{o}$ - температура в градусах C.

Наявність нерівностей рельєфу поверхні вносить додаткові втрати енергії. В цьому випадку необхідно визначити ефективні параметри підстильної поверхні.

Якщо місцевість средньопересічна - то ефективні значення питомої провідності можуть зменшуватися в 2...4 рази. Відносна діелектрична проникність при цьому практично не змінюється.

Оцінку ефективних електричних властивостей грунту досить визначити лише в межах області, суттєвої для поширення радіохвиль. Ї̈̈ максимальна ширина в середині траси становить $\sqrt{\lambda \cdot \frac{r}{3}}$. Найбільш важливими є кінцеві ділянки траси, що примикають до передавальної і приймальної антени.
Саме для кінцевих ділянок і слід визначати параметри земної поверхні. Вплив на більшій частині траси між кінцевими ділянками має значно менше значення. Тому, якщо антени розташовані на досить рівних і відкритих ділянках місцевості, то можна не враховувати нерівності на трасі, порівняними з довжиною хвилі (пагорби, яри, дерева, гаї та інше) і непротяжними неоднорідностями грунту (струмки, річки, невеликі озера і болота та інше), вважаючи поверхню землі рівною.

У тих випадках, коли кінцевим ділянкам траси можна приписати однакові електричні параметри, траса вважається однорідною.

Якщо на трасі, особливо на іiї кінцях, є протяжні ділянки, ефективна провідність яких різниться на порядок і більше, для уточнення розрахунків трасу слід розподілити на дві-три ділянки і скористатися формулами для неоднорідних трас.

Рівень атмосферних завад носить квазістаціонарний характер і залежить від географічних координат пункту прийому, порівняно повільно змінюється протягом доби і від сезону до сезону.

Це дозволяє прогнозувати рівень атмосферних завад. Такі прогнози підсумовано в [9]. Для північних широт $\left(20 \ldots 70^{\circ}\right)$ залежність медіанних значень ефективної шумової температури атмосферних завад від частоти для різних сезонів показана графіками на рис. 2.

Крива 1 відповідає максимальним, а крива 5 мінімальним значенням атмосферних завад в діапазоні частот. Для практичних розрахунків рекомендується використовувати згладжені криві 2 - ніч, 3 ранок (вечір), 4 - день, що отримані в результаті усереднення по безлічі $T_{a m}$.

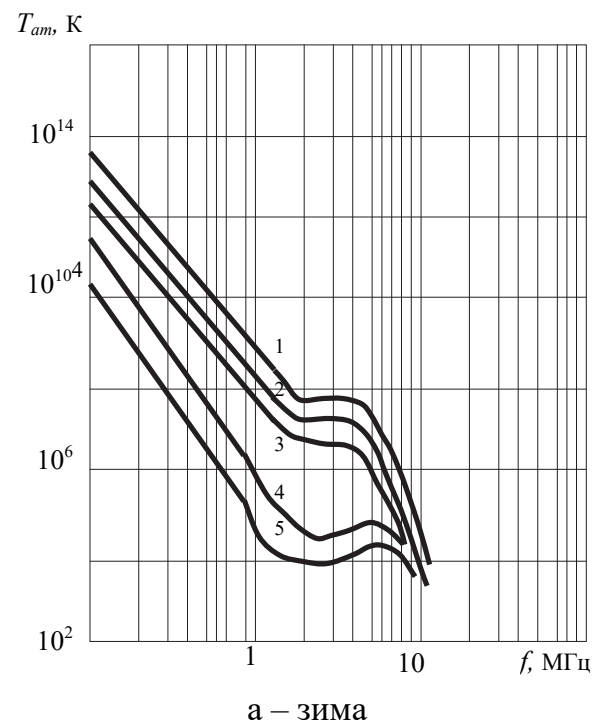

Рис. 2. Ефективна шумова температура атмосферних завад (початок)

Джерело: розроблено авторами за даними [9]. 

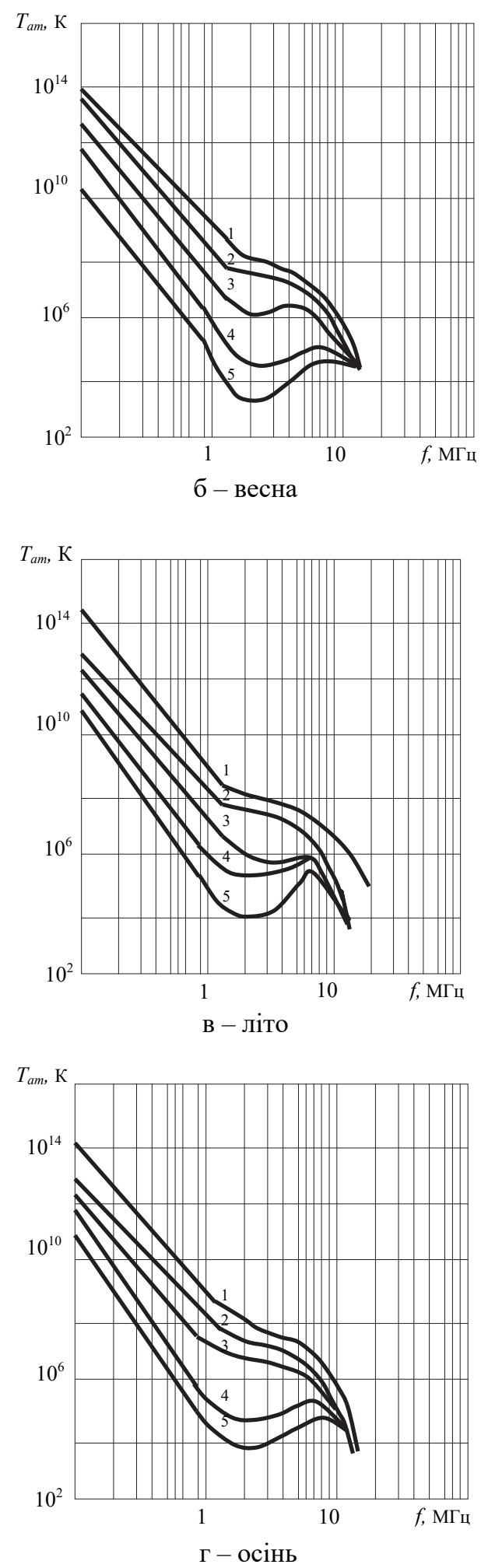

Рис. 2. Ефективна шумова температура атмосферних завад (закінчення)

Джерело: розроблено авторами за даними [9].

Дані про рівень індустріальних завад наводяться в [9]. Ефективна шумова температура індустріальних завад визначається з графіків на рис. 3 .

На основі статистичних даних робіт [10-11] були знайдені значення шумової температури станційних завад для середньої смуги Європи, які наведені на рис. 4.

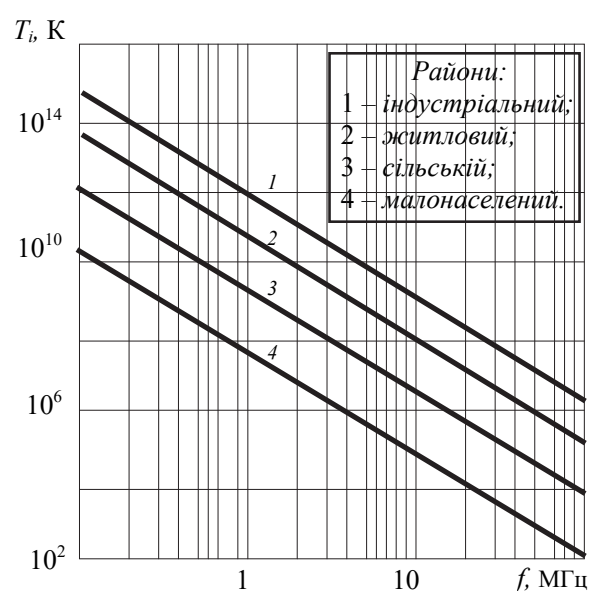

Рис. 3. Ефективна шумова температура індустріальних завад

Джерело: розроблено авторами за даними [2, С. 8$]$.

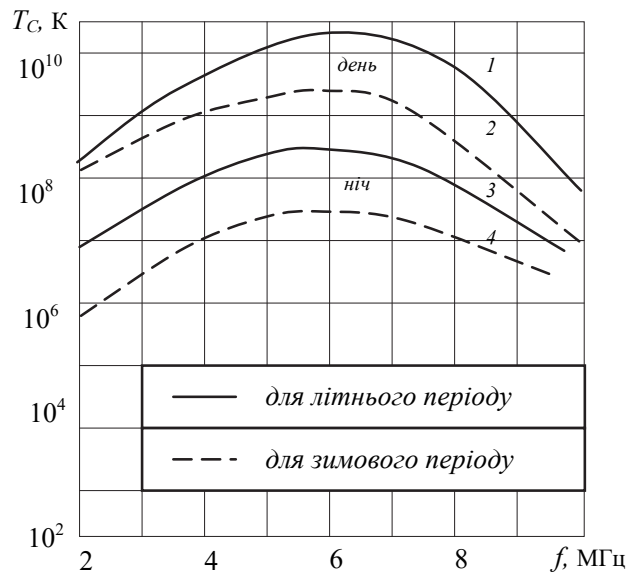

Рис. 4. Ефективна шумова температура станційних завад

Джерело: розроблено авторами за даними [10-11].

Для автоматизації розрахунків необхідно автоматизувати знімання вихідних даних 3 наведених графіків. Для цього їх треба оцифрувати. 3 цією метою спочатку на кожному графіку обираємо кілька вузлових точок і їх координати записуємо у вигляді векторів вихідних даних. Потім за допомогою вбудованих засобів Mathcad виконуємо сплайнапроксимацію кожного графіка за обраними вузловими точками. При цьому початкова функція замінюється відрізками кубічних поліномів, що проходять через три суміжні вузлові точки.

Сказане проілюструємо на прикладі оцифровки графіка 1 (рис. 3) за допомогою наступного фрагмента Mathcad-документа (рис. 5).

Матриця вихідних даних в даному випадку $\epsilon$ координати дев'яти вузлових точок графіка 1 (верхнього). В результаті сплайн-апроксимації ми для будь-якого значення частоти в межах від 2 до 10 МГц (наприклад 4,5 МГц) отримуємо значення 
ефективної шумової температури станційних завад $T_{c}$ (в даному випадку $2,04 \cdot 10^{10} \mathrm{~K}$ ).

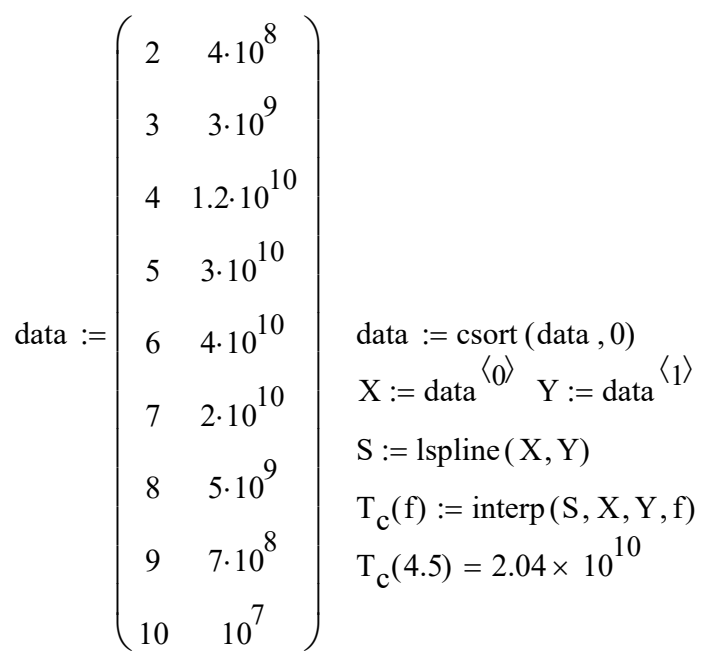

Рис. 5. Фрагмент Mathcad-документа по сплайн-апроксимації

Джерело: розроблено авторами.

Графік апроксимуючої функції, побудований за допомогою засобів Mathcad, наведено на рис. 6.

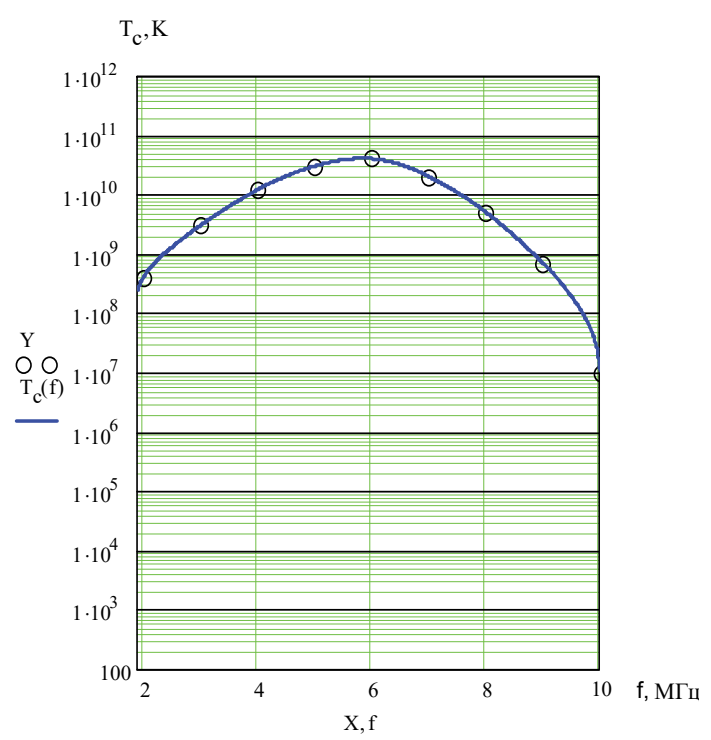

Рис. 6. Графік, який отриманий за допомогою сплайн-апроксимації

Джерело: розроблено авторами.

Неважко побачити, що він нічим не відрізняється від початкового графіка 1 рис. 4. Але знімання вихідних даних стосовно $T_{c}$ тепер автоматизовано.

Значення $h_{o}$ в залежності від виду роботи і допустимих втрат достовірності (розбірливості) зв'язку можуть бути взяті з відповідних таблиць, наприклад [2], або $з$ характеристик конкретної системи радіозв'язку (радіонавігації).

\section{Висновки}

Розроблено методику автоматизованого розрахунку радіолінії при зв'язку земною хвилею з метою визначення граничної дальності забезпечення радіозв'язку (радіонавігації) з заданою якістю. Методика базується на використанні аналітичних залежностей та автоматизована за допомогою прикладного математичного пакету Mathcad.

У результаті виключена процедура освоєння графоаналітичної методики та рутинні розрахунки, що пов'язані $з$ нею. Для роботи із запропонованою методикою виконавець повинен володіти хоча б первинними навичками роботи в середовищі Mathcad.

Результати розрахунків, проведених за запропонованою методикою, при однакових вихідних даних повністю збігаються з результатами, отриманими при використанні графіків, наведених в [16], що підтверджує достовірність даної методики.

Необхідно зазначити, що всі існуючі методики, в т.ч. i “Рекомендації МСЕ”, що стосуються розрахунку радіоліній зв'язку земної хвилею, включаючи і запропоновану методику, розроблені в припущенні, що напруженість поля земної хвилі в точці прийому $є$ постійною величиною, яка залежіть від випромінюваної потужності, робочої частоти і усереднених електричних параметрів підстилаючої поверхні. Однак експериментальні дослідження, що проведені в [1617], показали, що напруженість поля в зоні обслуговування не постійна, а змінюється випадковим чином, як у просторі, так і у часі, утворюючи поле випадкових чисел 3 цілком певними статистичними характеристиками. Відзначається, що наявного на даний час матеріалу явно недостатньо для розуміння природи цих явищ, в т.ч. на рівні МСЕ. Проте, випадковий характер корисного і завадового сигналу навіть в світлий час доби (тобто без урахування впливу іоносферної хвилі) зумовлюють необхідність ймовірнісної оцінки напруженості поля і відношення сигнал/перешкода на території обслуговування при розробці вдосконалених методик розрахунку.

Розглянута методика може бути застосована у тих випадках, коли потрібні багаторазово повторювані розрахунки радіоліній з різними вихідними даними, зокрема, при обгрунтуванні основних технічних параметрів засобів радіозв'язку і радіонавігації, що працюють в діапазонах кілометрових, гектаметрових і декаметрового хвиль на етапі їх проектування (модернізації, закупівлі).

Методика була неодноразово використана при виконанні науково-дослідних робіт і оперативних завдань.

\section{Список літератури}

1. Красюк Н.П. Электродинамика и распространение радиоволн / Н.П. Красюк, Н.Г. Дымович. - М.: Высш. школа, 1974. -563 с. 
2. Нарышкин Е.М. Волновая служба и антенные устройства. Часть 1. Теория электромагнитного поля и распространение радиоволн / Е.М. Нарышкин, В.П. Серков. - М.: МО СССР, 1982. - 288 с.

3. Фейнберг Е.Л. Распространение радиоволн вдоль земной поверхности / Е.Л. Фейнберг. - М.: Наука, 1999. $496 \mathrm{c}$.

4. Азрилянт П.А. Численные результаты теории дифракции радиоволн вокруг земной поверхности / П.А. Азрилянт, М.Г. Белкина. - М.: Сов. радио, 1957. - 46 с.

5. Марков Г.Г. Математические методы прикладной электродинамики / Г.Г. Марков, Е.Н. Васильев. - М.: Сов. радио, 1970. $-563 \mathrm{c}$.

6. Кашпровский В.Е. Расчёт поля земной волны средневолновых станций / В.Е. Кашпровский, Ф.А. Кузубов. М.: Электросвязь, 1967. -98 с.

7. Фок В.А. Проблемы дифракции и распространения электромагнитных волн / В.А. Фок. - М.: Сов. радио, 1970. $-520 \mathrm{c}$.

8. Мешалкин В.А. Основы энергетического расчёта радиоканалов / В.А. Мешалкин, В.В. Сосунов. - С.: ВАС, 1991. $-110 \mathrm{c}$.

9. CCIR 322-2: Characteristics and Applications of Atmospheric Radio Noise Data, International Radio Consultative Committee, Geneva, 1983. - 78 p. - Режим доступу: http://search.itu.int/history/HistoryDigitalCollectionDocLibrary/ 4.281.43.en.1018.pdf.

10. Комарович В.Ф. Случайные радиопомехи и надёжность КВ связи / В.Ф. Комарович, В.И. Сосунов. - М.: Связь, 1977. $-136 \mathrm{c}$.

11. Прохоров В.Н. Надёжность радиосвязи в условиях воздействия случайных помех и пути её повышения / В.Н. Прохоров, А.Н. Шаров. - Л.: ВАС, 1982. - 132 с.

12. Юрьев А.Н. Методика расчета максимальной дальности связи, обеспечиваемой системой радиосвязи по земной волне / А.Н. Юрьев // Омский научный вестник Омского государственного технического университета. - 2011. № 1(97). - C. 216-220. Офіційний сайт PTC MATHCAD. Mathcad: Math software for your engineering calculations. - Pежим доступу: https://www.mathcad.com.

13. Офіційний сайт Britannica. Surface wave propagation. - Режим доступу: https://www.britannica.com/ science/surface-wave-propagation.

14. Angulo I. Handbook on Ground Wave Propagation [Електронний ресурс] / I. Angulo, L. Barglay. - Geneva: Radiocommunication Bureau, 2014. - 59 p. - Режим доступу: https://www.itu.int/dms_pub/itu-r/opb/hdb/R-HDB-59-2014PDF-E.pdf.

15. Recommendation ITU-R P.368-9 (02/2007). Ground-wave propagation curves for frequencies between $10 \mathrm{kHz}$ and 30 MHz. P Series Radiowave propagation Internacional Telecommunication Union (ITU), 2007. - P. 3-54. - Режим доступу: https://www.itu.int/dms_pubrec/itu-r/rec/p/R-REC-P.368-9-200702-I!!PDF-E.pdf.

16. Чернов Ю.А. Распространение радиоволн и прикладные вопросы / Ю.А. Чернов. - М.: Техносфера, 2017. 682 c. - Режим доступу: https://www.rfbr.ru/rffi/ru/books/o_2053259\#1.

17. Чернов Ю.А. Сезонные изменения напряжённости поля земной волны в дневное время в НЧ, СЧ диапазонах / Ю.А. Чернов // Труды НИИР. - 2005. - № 9. - С.109-115.

\section{Відомості про авторів:}

\section{Костенко Ігор Леонідович}

кандидат військових наук старший науковий співробітник начальник управління

Харківського національного

університету Повітряних Сил ім. І. Кожедуба, Харків, Україна

https://orcid.org/0000-0003-4594-7727

\section{Поздняк Валерій Павлович}

науковий співробітник

Харківського національного

університету Повітряних Сил ім. І. Кожедуба,

Харків, Україна

https://orcid.org/0000-0001-7247-9944

Блащук Світлана Миколаївна

кандидат технічних наук

провідний науковий співробітник

Харківського національного університету

Повітряних Сил ім. І. Кожедуба,

Харків, Україна

https://orcid.org/0000-0001-9230-9045

\section{Information about the authors:}

\section{Igor Kostenko}

Candidate of Military Sciences

Senior Research

Chief of Department

of Ivan Kozhedub Kharkiv

National Air Force University,

Kharkiv, Ukraine

https://orcid.org/0000-0003-4594-7727

\section{Valerii Pozdniak}

Research Associate

of Ivan Kozhedub Kharkiv

National Air Force University,

Kharkiv, Ukraine

https://orcid.org/0000-0001-7247-9944

\section{Svetlana Blashchuk}

Candidate of Technical Sciences

Lead Research

of Ivan Kozhedub Kharkiv

National Air Force University,

Kharkiv, Ukraine

https://orcid.org/0000-0001-9230-9045 
Казіміров Олександр Олексійович кандидат військових наук доцент доцент кафедри

Національної академії

Національної гвардії України, Харків, Україна

https://orcid.org/0000-0002-7509-5118

Поляцко Володимир Васильович начальник центру зв'язку об'єднаного штабу Командування Об'єднаних сил Збройних Сил України, Київ, Україна https://orcid.org/0000-0002-4111-7956

\section{Oleksandr Kazimirov}

Candidate of Military Sciences Associate Professor

Senior Lecturer

of the National Academy

of the National Guard of Ukraine,

Kharkiv, Ukraine

https://orcid.org/0000-0002-7509-5118

\section{Volodymyr Poliatsko}

Chief of the Communications Center of the Joint Staff of the Joint Forces Command of the Armed Forces of Ukraine,

Kyiv, Ukraine

https://orcid.org/0000-0002-4111-7956

\title{
МЕТОДИКА АВТОМАТИЗИРОВАНОГО РАСЧЕТА РАДИОЛИНИЙ ПРИ СВЯЗИ ЗЕМНОЙ ВОЛНОЙ
}

\author{
И.Л. Костенко, В.П. Поздняк, С.Н. Блащук, А.А. Казимиров, В.В. Поляцко
}

В статье приведена методика автоматизированного расчета радиолинии при связи земной волной в диапазонах километровых, гектометровых и декаметровых волн с иелью определения предельной дальности обеспечения радиосвязи (радионавигации) с заданным качеством с помощью прикладного математического пакета Матһсаd. Известно, что предельная дальность радиосвязи (радионавигации) достигается тогда, когда реальное ослабление, которое определяется поглощением на трассе распространения, равно предельно допустимому ослаблению, которое зависит от помеховой обстановки в точке приёма, необходимого качества приёма и технических характеристик передающего и приемного устройств. Предельно допустимое ослабление на трассе определяем, исходя из основного уравнения радиосвязи и условий осуществления радиосвязи. Реальное (фактическое) ослабление сигнала на трассе распространения рассчитьвается с учетом множителя ослабления на любой трассе. Решение дифракиионной задачи заключается в решении волнового уравнения в сферической системе координат при учете граничных условий на поверхности гладкой земли и учете особенностей характеристик поля вблизи излучателя.

Ключевые слова: дальность радиосвязи, допустимое ослабление, дифракиия, земная волна, электрические параметры грунта, Mathcad, распространение радиоволн.

\section{METHOD OF AUTOMATED CALCULATION OF RADIOLINES DURING EARTH WAVE COMMUNICATION}

\section{Kostenko, V. Pozdnyak, S. Blashchuk, O. Kazimirov, V. Poliatsko}

The article contains a technique for the automated calculation of radio link when communicating with earth wave in the ranges of kilometer, hectometer and decameter waves in order to determine the maximum range of radio communication (radio navigation) with a given quality using the applied Mathcad mathematical package. It is known that the maximum range of radio communication (radio navigation) is achieved when the real attenuation, which is determined by absorption on the propagation path, is equal to the maximum allowable attenuation, which depends on the interference environment at the reception point, the required reception quality and the technical characteristics of the transmitting and receiving devices. We find the maximum allowable attenuation on the path based on the basic equation of radio communication and the conditions for radio communication. The real (actual) attenuation of the signal along the propagation path is calculated taking into account the attenuation multiplier on any path. The solution to the diffraction problem consists in solving the wave equation in spherical coordinate system taking into account the limiting conditions on the surface of smooth earth and the features of the field near the emitter. It should be noted that all existing techniques, including all MCE-R Recommendations concerning the calculation of ground-wave radio links, including the proposed methodology, developed on the assumption that the ground-wave field strength at the receiving point is a constant value that depends on the radiated power, operating frequency and average electrical parameters of the underlying surface. However, the springiness of the field in the service area is not constant, but changes randomly, both in space and in time, forming a field of random numbers with well-defined statistical characteristics. The methodology is considered can be applied in cases where repeated calculations of radio lines with different initial data are required, in particular, when substantiating the main technical parameters of radio communication and radio navigation equipment operating in the ranges of kilometer, hectare and decameter waves at the stage of their design (modernization, procurement).

Keywords: radio communication range, allowable attenuation, diffraction, ground wave, electrical parameters of the soil, Mathcad, propagation of radio waves. 